\title{
EDUCATORS' DIGITAL COMPETENCE IN SWEDISH RURAL SCHOOLS
}

\author{
Gerd Pettersson, Gunilla Näsström, Umeå University, Sweden
}

\begin{abstract}
This article presents a survey census study performed in a small, remotely located municipality with four rural schools in the north of Sweden. The study is part of a larger project, Remote Consulting in special needs education between special educators and class teachers, the aim of which is to increase the equivalence between the municipality's schools by giving more class teachers improved access to special needs education (SNE) consultations provided by special educators via remote consulting.

Prior to the start of the project, a questionnaire was sent out to all the class teachers in the participating schools. All the teachers approached answered the questionnaire. One of the aims of the survey was to gain increased knowledge about the teachers' self-efficacy in their use of ICT. The most intriguing result was that three of the five 50-59 year-old teachers estimated their knowledge about ICT to be above average compared to that of their colleagues. A similar pattern was identified in the teachers' use of ICT in their teaching. Of those who used ICT every day, three were 30-39 years old, three were 50-59 years old and one was 40-49 years old, while all of those who used ICT less than once a week were younger than 39. The results of the study indicate that the teachers in this study are adequately equipped to proceed from physical counselling to remote consulting in special needs education.
\end{abstract}

\section{Abstract in Sweden}

I artikeln presenteras och analyseras resultaten från en webbaserad enkätstudie som riktade sig till samtliga klasslärare i fyra glesbygdsskolor, i en mindre kommun i norra Sveriges inland. Alla lärare besvarade enkäten. Syftet är att belysa om lärarnas självskattade IKT-förmåga kan utgöra en grund för specialpedagogisk fjärrhandledning.

Studien är en del i ett pågående och omfattande projekt benämnt, Specialpedagogisk fjärrhandledning, där det övergripande syftet är att öka likvärdigheten mellan kommunens skolor genom att fler klasslärare ges tillgång till fler specialpedagogiska handledningstillfällen, som i sin tur kan bidra till att fler elever får den specialpedagogiska verksamhet de har behov av.

Det mest intressanta resultatet var att tre av fem, 50-59-åriga klasslärare uppskattade den egna IKTkompetensen över genomsnittet jämfört med hur de bedömde kollegornas IKT-kompetens. Ett liknande mönster identifierades i lärarnas användning av IKT i den egna undervisningen. Av dem som använde IKT varje dag var tre klasslärare 30-39 år, tre klasslärare var 50-59 år medan en klasslärare tillhörde svarskategorin 40-49 år, alla som angav att de använde IKT mindre än en gång i veckan var yngre än 39 år. Studiens resultat indikerar att lärarna i denna studie är tillräckligt 
rustade för att gå från fysisk specialpedagogisk handledning till specialpedagogisk fjärrhandledning.

Keywords: Class teacher, Digital communication, Remote Consulting, Rural Schools, Special Needs Education, Special Educator

\section{Introduction}

Teachers in rural schools may need to rethink past and present educational traditions in the light of the opportunities provided by digital communication technology. These challenges have resulted in considerable demands being placed on teachers to develop the digital competences needed for providing high-quality and equal teaching. According to Pettersson (2017), an essential challenge for rural schools is to ensure that all students have access to equal and inclusive education, which in the long run will create social and economic benefits for both individuals and society. Nilholm and Göransson (2013) state that certain criteria must be met in order for a learning environment to be inclusive. A key characteristic of such an environment is that the school does not differentiate between the students, i.e. that all students take part in the school's regular teaching activities. Another characteristic is that there is a sense of community among the students characterised by participation and democratic opportunities, which makes them educationally and socially engaged in the school's learning environment. Moreover, it is important that the school regards student diversity as an asset. Thus, inclusion should be understood in relation to the teachers' professional qualifications and the school situation of the individual student.

Teachers, especially those who work in rural schools, have to deal with many issues on their own, ranging from administrative duties to behaviour management (Karlberg-Granlund, 2009; McHenry-Sorber \& Schafft, 2014; Pettersson, Ström, \& Johansen, 2016). Educational challenges caused by students' different learning needs, combined with a lack of special educators, may also place added strain on rural school teachers (Pettersson \& Näsström, 2019; Tuters, 2015). When a special educator is not available and a teacher has few, if any, colleagues to ask for advice, the situation can be especially challenging (Kuhl, Pagliano, \& Boon, 2014). As shown in previous Swedish research (cf. Nilholm \& Göransson, 2013) and in Swedish national special education documents (cf. SPSM, 2013; SKOLFS, 2014), all schools see inclusive learning environments as desirable but difficult to achieve in practice. According to Pettersson (2017), teachers in rural schools find ways of working in special needs education (SNE) which function satisfactorily in an inclusive learning environment. Rural schools in Sweden have the same obligation as other schools to offer equal education to all students (SFS 2010:800), and from June 2015, schools can use remote teaching in certain subjects where they lack qualified teachers (SFS 2010:800).

In 2017, the Swedish government proposed a strategy for the digitalisation of Swedish schools (Department of Education, 2017) and later also new plans for this process in the Swedish National Curriculum for compulsory school (Lgr 11). The digitalisation process (Lgr 11) and teachers' digital competence and use of digital tools have consequences for teachers' work, as digital tools have to be integrated more and more into the teaching (Department of Education, 2017; Lgr 11). The plans for the digitalisation of schools and teachers' use of digital tools could justify general studies of 
teachers' views on their own and their colleagues' competence in information and communication technologies (ICT).

By using digital tools in their teaching, teachers can improve their students' prerequisites for learning as the students will receive and develop digital competence for further studies and working life (Skolverket, 2018). Teachers' use of ICT in rural schools is a starting point to create knowledge about teachers' experience and use of ICT in their teaching, as well as about their ability to use ICT, as this is a prerequisite for a successful implementation of remote consulting in SNE. Rural schools exist mostly in sparsely populated, remote areas. Picciano and Seaman (2007) point out that professional development in ICT for teachers is required in order to overcome knowledge barriers. Our interest in rural schools is due to the fact that these schools tend to send out "weak signals", meaning that the schools do not themselves have the capacity to make their voices heard because of ever-shrinking populations and social and demographic changes in their areas (Karlberg-Granlund, 2011; Lind \& Stjernström, 2015), which may ultimately lead to school closures (Uba, 2015; Pettersson, 2017).

Teachers' ICT competence and use of ICT tools in their teaching in four Swedish rural schools in one municipality is the context for the study. The aim is to shed light on if teachers' self-assessed ICT ability can lay a foundation for remote consulting in SNE.

\section{Rural schools}

Researchers have identified a number of common rural school features, namely geographic isolation, low number of teachers and students, multi-grade classrooms, diverse learning needs among students, lack of support staff, multifaceted work duties for teachers and scarce professional development opportunities (Bæck, 2015; Berry, 2012; Kalaoja \& Pietarinen, 2009; Kvalsund, 2009; Malloy \& Allen, 2007; Pettersson, Ström, \& Johansen, 2016; Åberg-Bengtsson, 2009). Previous research on rural schools has shown that teachers working in such schools face working conditions that are different from those of teachers in urban schools (Anderson \& Lonsdale, 2014; Howley \& Howley, 2014; Kalaoja \& Pietarinen, 2009; Kvalsund, 2009; Monk, 2007; Pettersson, Ström, \& Johansen, 2016; Åberg-Bengtsson, 2009). For example, these differences relate to the composition of the student body, number of students, teachers and support staff, organisation of instruction and professional development opportunities. Other challenges for rural schools include ongoing demographic and social changes, shrinking populations, financial constraints and a constant fear of school closures (Autti \& Hyry-Beihammer, 2014; Egelund \& Lausten, 2006; Hargreaves, 2009; Kearns, Lewis, McCreanor, \& Witten, 2009; Pettersson, 2017; Uba, 2015). Thus, teachers working in rural schools are likely to face many different challenges in their daily work.

Rural schools also differ across, as well as within, countries. Because of demographic and geographic differences, there is no common definition of what constitutes a rural school (Anderson, 2010). Many researchers use the number of students as a criterion, which can be misleading. For example, a rural school in America may have up to 350 students (Anderson, 2010), while a Scottish or British rural school rarely has more than 120 students (Hargreaves, 2009; Wilson $\&$ McPake, 1998). This indicates that it is not possible to use the number of students as the sole 
criterion. Another challenge in defining rural schools is the fact that such schools in different countries are located in different rural contexts (Anderson, 2010; Kimonen \& Nevalainen, 2013). Given these differences in criteria, making comparisons of rural schools across countries is difficult.

\section{Rural Schools in a Swedish context}

The study of rural education in Sweden is also complicated by the fact that there is no official definition of the terms rural area or rural school. Different authorities use different definitions. In order to overcome the problem of a missing official definition of a rural school, Pettersson (2017) identified a number of common characteristics of rural schools, based on empirical evidence from 58 rural schools located in the northern part of Sweden. Pettersson concludes that the characteristics of the 58 rural schools are representative of rural schools in Sweden, regardless of their geographical location. The common rural school characteristics described in Pettersson (2017) are of a geographical, demographic, statistical, managerial, competence-related, educational, social, contextual and economic nature.

Rural schools are geographically located in a sparsely populated coastal regions, on islands or in an inland or mountain region. Demographically, rural schools are located in sparsely populated communities in municipalities of various sizes. The schools are peripherally located in relation to the municipality centre at a distance from the centre that varies depending on geographical conditions. Most of these communities appear to be viable and one measure of their vitality is the number of students in the school. The statistical characteristic is that rural schools have between 33 and 55 students. On average, the schools employ 3.7 class teachers and the student groups are characterised by great variation. The managerial characteristic is that the head teachers lead the schools remotely from the municipality centres, which are located, on average, 3 kilometres from the schools. The competence-related characteristic is that rural schools usually have qualified class teachers. The pedagogical (educational) characteristic is that the teaching takes place in age-mixed groups which form the schools' classes. In these composite age groups, the teachers teach several courses in parallel at the same time. The teaching environment is calm and safe, which means that the class teachers can pay early attention to the needs of their students. The social characteristic is that the learning environment is characterised by social coexistence, well-being and good relations established through well-functioning cooperation between all school stakeholders. The contextual characteristic is that the rural schools have a significant position in their respective communities. The economic characteristic, finally, is that the rural schools have poor finances, which requires the teachers to practice strict economy.

In the light of these characteristics, Pettersson (2017) concludes that rural schools broadcast "weak signals" that are only rarely perceived by politicians or researchers. This constitutes a strong incentive for the present study. 


\section{Teachers' digital competence}

National and international initiatives to implement ICT in educational systems have been taken by, for example, the European Commission (2013). The digitalisation of society affects the education provided by the schools, as well as the teachers (European Commission, 2013). One of the so-called key competences identified by the European Union is the ability to use ICT. Thus, it seems worthwhile to contribute knowledge about how teachers in Swedish rural schools use ICT. The European strategy on key ICT skills and schools' opportunities to use remote teaching might motivate teachers in rural schools to use ICT for special needs consulting by specialised teachers and thus improve their opportunities to provide equivalent education for all their students.

Krumsvik (2011) stresses the importance of having knowledge about teacher self-efficacy in their use of ICT. In this context, "self-efficacy" refers to teachers' belief and confidence in being capable to provide good teaching (Christophersen, Elstad, Turmo, \& Solhaug, 2016). Digital technology offers various new teaching methods which will help the teachers to vary their teaching approaches. (Drijvers et al., 2010). As teachers practice their digital skills together with their students in the classroom, the students' digital skills will develop, which means that the teachers, in their turn, need to further develop and apply their digital skills (Krumsvik 2009). This requires that teachers have the knowledge, will and skills to perform digital activities and create digital learning environments (Ferrari, 2012).

Digital competence and technology integration into teaching practices are conducive to developing teachers' collaboration with their students (Spiteri \& Rundgren, 2017). Bai et al. (2016) found that when ICT was integrated into teaching, students' test scores improved. This was more important for low-performing students than for high-performing ones. The same study found that if ICT was introduced into schools without being integrated into teaching, there was no improvement in students' test scores compared to those of a control group.

However, there are also studies that point to the need for a clearer pedagogical and didactic development focus (see, for example, Hague, 2014; Jahnke \& Kumar, 2014; Jahnke et al. 2017; Käck, 2019; Olofsson \& Lindberg, 2014; Perrotta \& Evans, 2013; Warschauer et al., 2014) in order for the schools' digitalisation to take off. As a result of the last-mentioned study above, the idea has emerged that the previous focus on access to digital technology should be replaced by a focus on pedagogical development, digital skills, student learning and teaching design choices (cf. Warschauer et al., 2014). Research has also pointed out a need for studies on, and development of, SNE remote consulting (cf. Pettersson, 2017; Pettersson \& Näsström, 2019).

Studies (see for example, Meyer \& Xu, 2009; Hsu \& Chen, 2018; Garcia-Martin \& Cantón-Mayo, 2019) show that use of digital tools and digital competence differs between teachers of different ages. Younger teachers tend to have more technological knowledge, according to Hsu and Chen (2018), while elder teachers experience more difficulties to keep up with the new technologies (Meyer \& Xu, 2009). Garcia-Martin and Cantón-Mayo (2019) found in in their study that teachers of different ages use different types of digital tools. Teachers younger than 30 use google more frequently than older teachers, while elder teachers seem to prefer wiki. 


\section{Special needs education consulting}

In this study, the concept "remote special needs education consultation" in the context of rural schools, is understood as a relational collaboration between a special educator and a teacher aimed at exchanging knowledge about a difficult problem which they try to find a joint solution to (Edwards, 2011; Edwards \& Daniels, 2012; Edwards et al., 2009). Working relationally across professional boundaries also involves the actors' capacity to communicate and exchange knowledge between each other (Edwards et al., 2009). Professionals in multidisciplinary teams have to share their expertise in order to complement their own knowledge with the knowledge of other professionals. In this way, their knowledge will increase and professional challenges can be successfully dealt with (Nowotny, 2003).

Remote consultation between special educators and teachers in rural schools in Sweden can be understood as a digital innovation in SNE (c.f. Pettersson, 2017). Therefore, it is of interest to study teachers' self-assessments and their assessments of their colleagues' digital competence.

\section{Method}

This study, which is a part of a project aimed at developing remote SNE consultation in four rural schools in a municipality in the north of Sweden, provides a view of the participating teachers' initial digital competence and use of ICT in their teaching. As all teachers in the project participated in the study, the study is a census for the four rural schools in the municipality. The objective is to show how teachers in these rural schools assess their digital competence and how they use ICT, but not to draw any general conclusions about teachers' digital competence and UCT use.

\section{Questionnaire}

In order to make reliable comparisons between the teachers, a questionnaire was used to collect data from the study participants. A questionnaire has the advantage of making it possible to collect comparable information from all participants and reduces the risk of interviewer effects (Cohen, Manion, \& Morrison, 2011). However, a questionnaire can also restrict the possible answers depending on its design. The questionnaire comprised 35 questions, 30 of which were closed questions and five open questions, i.e. questions to which the teachers could write their own responses. Eleven of these questions concerned the participants' backgrounds: age, previous education, type of teacher qualification, general teaching experience and experience of teaching in rural schools. In a second section of the questionnaire, eight questions were asked about the participants' digital competence (2 questions), use of ICT in the classroom (2 questions) and their expectations of remote SNE consultation (4 questions). In this study, digital competence means knowledge about, and use of, ICT. The questions about digital competence and use of ICT in the classroom, are inspired of a questionnaire used by Håkansson-Lindqvist (2015). The formulation of the questions about expectations of remote consultations were based on the aim of the larger project, "Remote Consulting in special needs education between special educators and class teachers". One of the questions was excluded because of problems with the response alternatives. A third section of the questionnaire contained questions about special education, which is not a part of this study. Therefore, no results are reported from the third part of the questionnaire. 


\section{Participants}

All twenty teachers in the participating schools answered the questionnaire. The project started in the spring of 2018 and the questionnaire was sent out online at the beginning of the project. Two newly employed teachers answered the questionnaire when they started their employment in August 2018. One teacher did not answer the question about how often he/she uses ICT in teaching.

One of the questions concerned the use of different kinds of ICT tools, namely telephone, email, chat, video chat, blog, wiki and communities. In the questionnaire, examples were given of some of these tools. A text message was used as an example of chat, Skype, MSN, Google Video and Facetime were used as examples of video chat and Facebook and Instagram exemplified communities.

\section{Analysis}

As this study is a census, descriptive statistics were used. SPSS was used as a tool for the statistical analyses. Frequencies, average and standard deviation are presented for the different questions. Pearson's $r$ is reported in the results section regarding correlations between different questions and the square of correlation is used as a measure of effect size (Abbott \& McKinney, 2013). A correlation between .10 and .29 shows a small effect size, a correlation between .30 and .49 an average effect size and a correlation of at least .50 a large effect size.

The twenty teachers participating in the study were divided into two groups based on their teaching qualifications. Six of the teachers had a preschool teacher or leisure-time pedagogue qualification and these formed one group, named Preschool Teachers. The rest of the teachers, who had a compulsory school teacher qualification, formed a group named Compulsory School Teachers. In the analysis, the participating teachers also formed groups based on their age (see Table 1). One teacher did not answer the question about how often he/she used ICT in teaching.

As this census study is quite small, with only 20 participating teachers, the generalisability of the results may be questioned. However, the ages of the participating teachers can be compared to ages of teachers nationally (see Table 1). A test of the significance, Chi-2, was performed which showed no significant difference between the study participants and the total population $(p=.91)$. This indicates that the teachers in the study are well representative of the entire population (all teachers in Sweden), at least as regards the age distribution.

Table 1: Teachers' age distribution, nationally and in the study (percentages). The national statistics are based on statistics from the Swedish National Agency for Education (2020) for the $2018 / 19$ school year.

\begin{tabular}{lcccccc}
\hline & -29 years & $30-39$ year & $40-49$ years & $50-59$ years & $60-65$ years & 66 years - \\
\hline Nationally & $10 \%$ & $23 \%$ & $32 \%$ & $23 \%$ & $10 \%$ & $2 \%$ \\
In the study & $5 \%$ & $20 \%$ & $30 \%$ & $30 \%$ & $15 \%$ & $0 \%$ \\
\hline
\end{tabular}




\section{Results}

Most of the teachers (12 of 19) estimated that their knowledge about ICT was average in comparison to that of the other teachers in their school (see Table 2). However, five teachers believed their knowledge was above average and two teachers below average. There are differences between the teachers in how often they use ICT in teaching together with their students (see Table 2). Seven of the teachers use it every day, while five teachers use ICT less than once a week. The correlation coefficient between their self-estimated level of knowledge about, and their use of, ICT is .51, indicating a large effect size. The correlation indicates that teachers who estimate their knowledge to be better than that of their colleagues' use ICT more often.

Table 2: The teachers' self-estimated level of knowledge about ICT in comparison to that of the other teachers in their school, in relation to how often they use ICT with the students in teaching. Number of teachers.

\begin{tabular}{lcccccc}
\hline & $\begin{array}{c}\text { Every } \\
\text { day }\end{array}$ & $\begin{array}{c}\text { A few days a } \\
\text { week }\end{array}$ & $\begin{array}{c}\text { Once a } \\
\text { week }\end{array}$ & $\begin{array}{c}\text { Once a } \\
\text { month }\end{array}$ & $\begin{array}{c}\text { Seldom or } \\
\text { never }\end{array}$ & Total \\
\hline $\begin{array}{l}\text { Above } \\
\text { average }\end{array}$ & 4 & 1 & 0 & 0 & 0 & 5 \\
$\begin{array}{l}\text { Average } \\
\text { Below }\end{array}$ & 3 & 3 & 2 & 2 & 2 & 12 \\
average & 0 & 1 & 0 & 0 & 1 & 2 \\
\hline Total & 7 & 5 & 2 & 2 & 3 & 19 \\
\hline
\end{tabular}

In order to find an explanation for the differences between the teachers, analyses of background variables were made, based on teacher category, teaching qualification and age.

The most obvious pattern was found in the analysis of the teachers' age (see Figure 1 and 2). Three of the five 50-59 year-old teachers and one teacher in each of the other age categories, except the 29 category, estimated that their knowledge about ICT was above average compared to that of their colleagues. Two teachers believed their knowledge was below average, one in the 60-65 age category and one in the -29 category. Of those who estimated that their knowledge was average, nine of twelve were between 30 and 49 years old. The level of ICT use shows a similar pattern (see Figure 2). Of those who use ICT every day, three were 30-39 years old, three were 50-59 years old and one was 40-49 years old. However, all of those who use ICT less than once a week were younger than 39. 


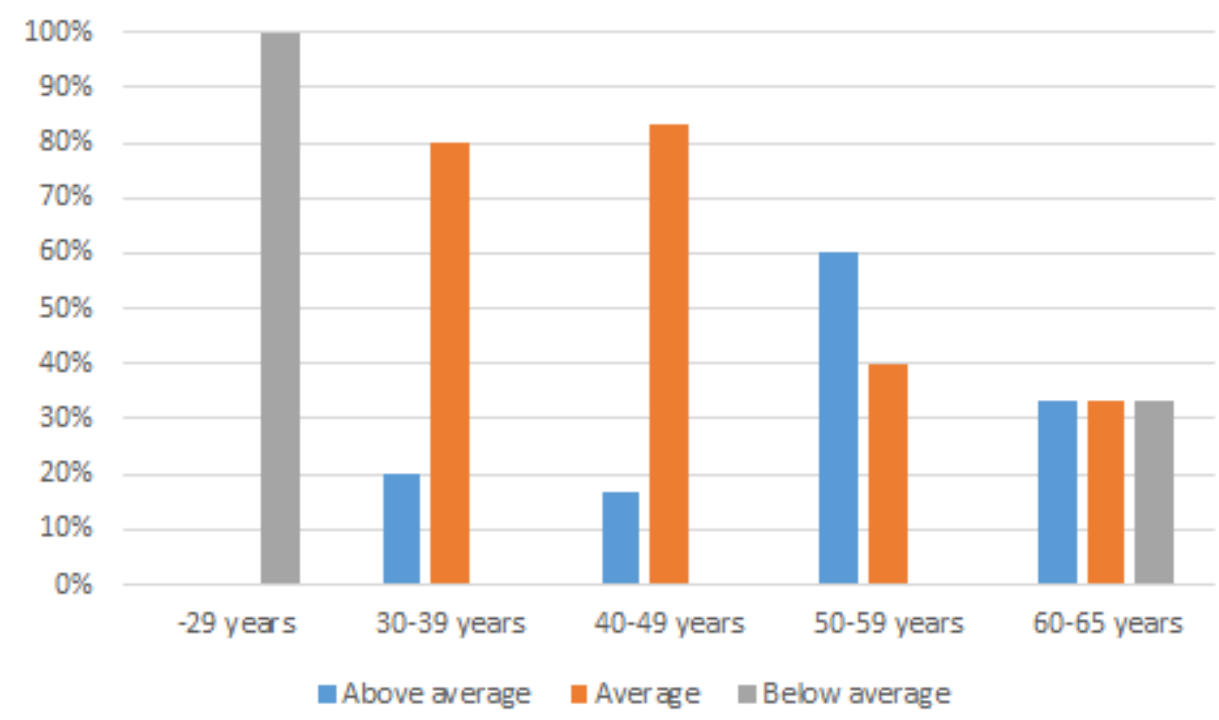

Figure 1. Teachers self-estimated level of knowledge about ICT compared to that of their colleagues, by age. (Number of teachers: -29 years: $1 ; 30-39: 5 ; 40-49: 6 ; 50-59: 5 ; 60-65: 3$ ).

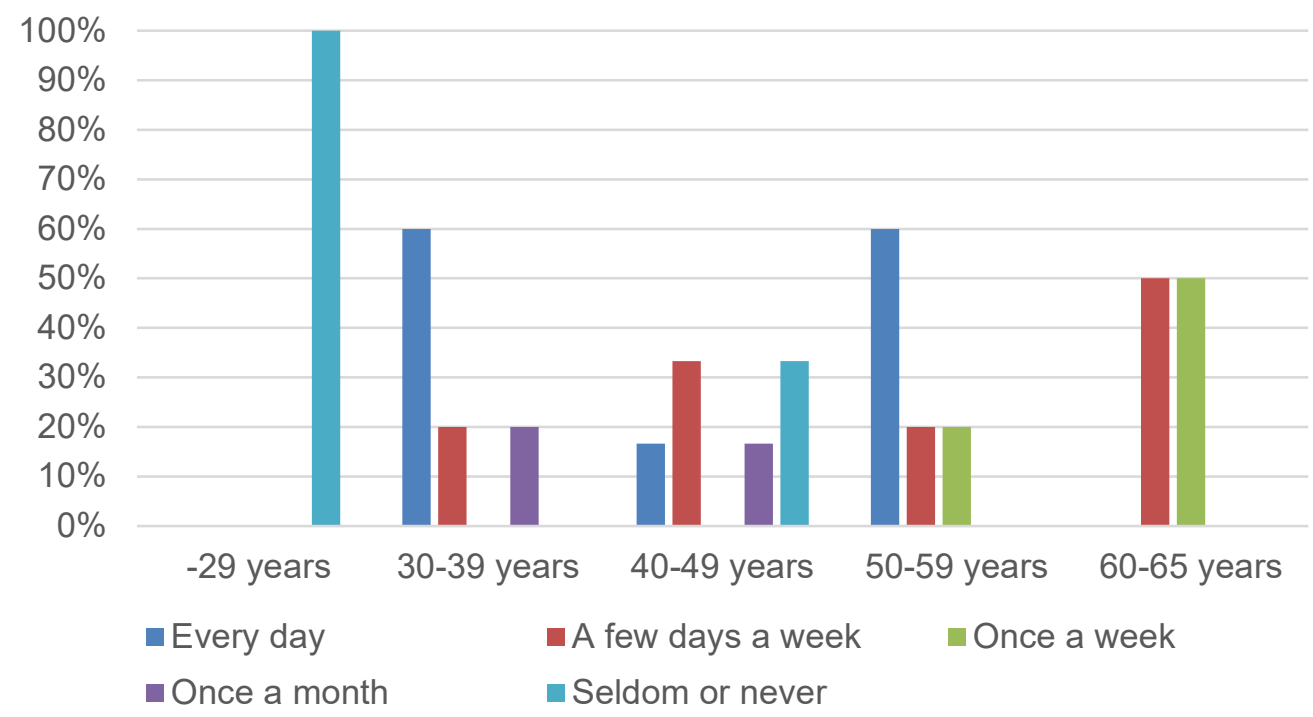

Figure 2. The teachers' self-estimated frequency of ICT use in teaching, by age. (Number of teachers: - 29 years: $1 ; 30-39: 5 ; 40-49: 6$; 50-59: 5; 60-65: 2 ).

Figures 3 and 4, show the results of the analysis based on teachers with different types of teaching qualifications. 


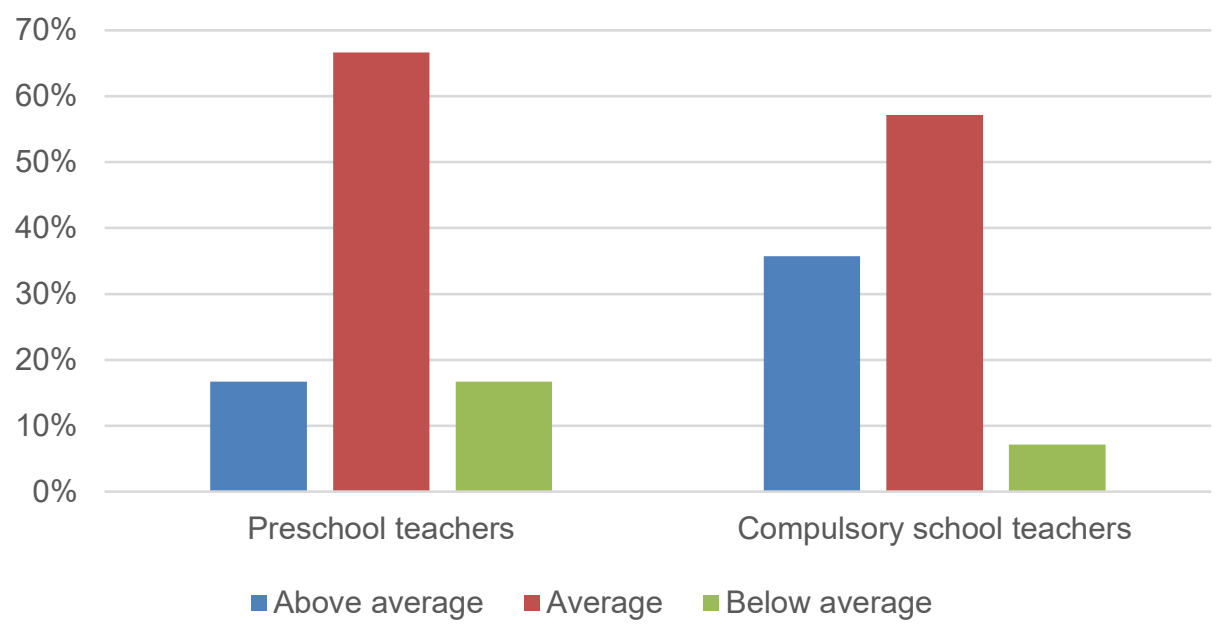

Figure 3. The teachers' self-estimated level of knowledge about ICT compared to other teachers in their school, by type of teaching qualification. (Number of teachers: Preschool: 6; Compulsory school: 14).

A larger proportion of the teachers with a compulsory school teacher qualification estimated their level of knowledge about ICT to be above average, as compared to teachers with a preschool teacher or leisure-time pedagogue qualification (see Figure 3).

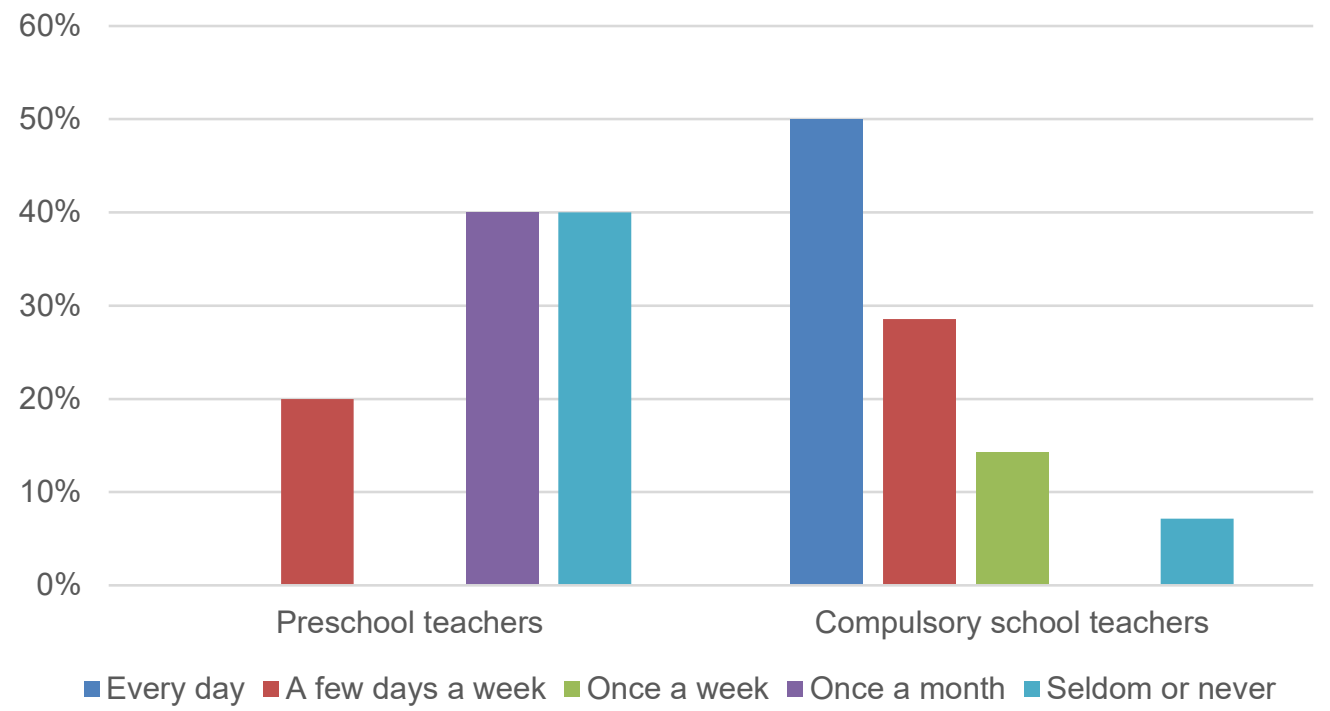

Figure 4. The teachers' self-estimated frequency of ICT use in teaching, by type of teaching qualification. (Number of teachers: Preschool: 5; Compulsory school: 14).

Half of the teachers with a compulsory school teacher qualification use ICT every day, as compared to none of teachers with a preschool teacher or leisure-time pedagogue qualification (see Figure 4). The latter group of teachers use ICT only rarely.

ICT can be used in teaching in different ways and Figure 5 presents how the teachers estimate the extent of their use of different ICT tools. 


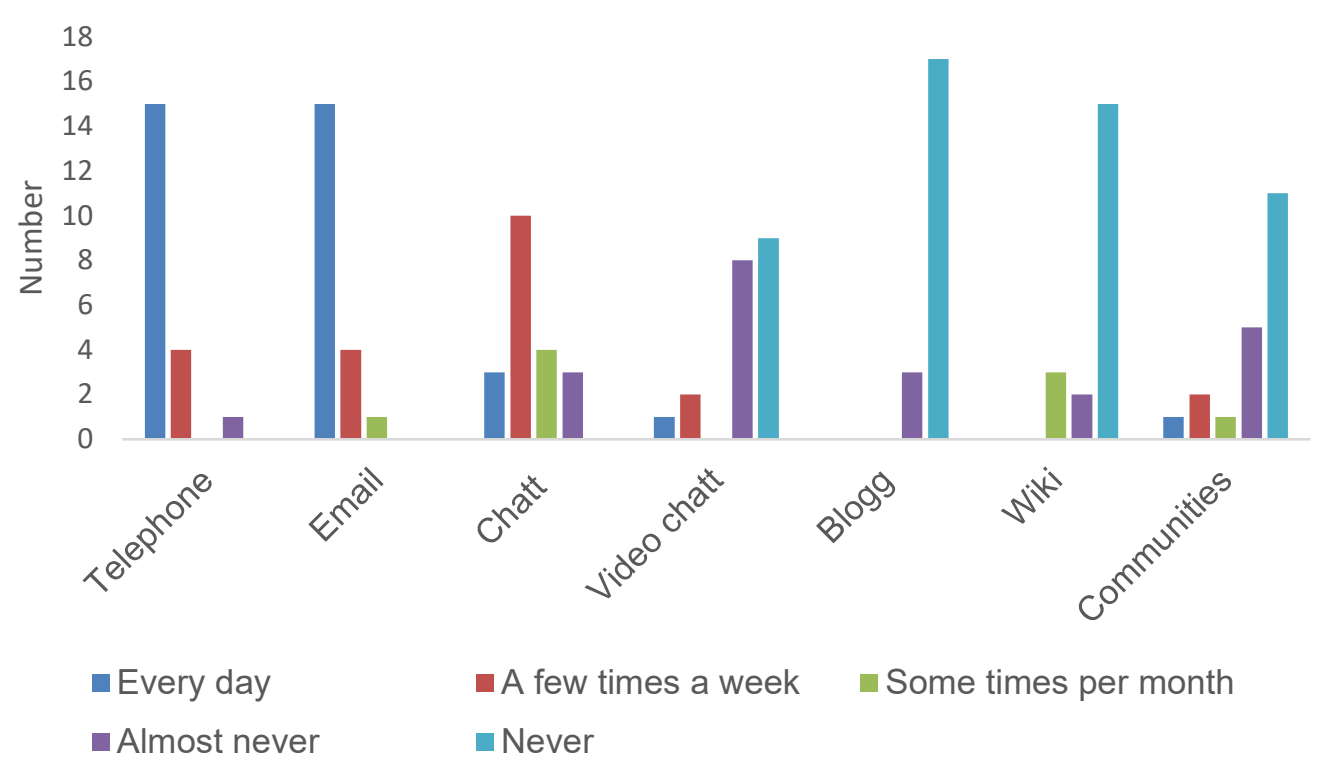

Figure 5. The teachers' self-estimated use of ICT communication tools in their teaching. Number of teachers (maximum 20 teachers).

The most frequently used ICT tools are telephone and email, while blogs, wikis and communities are the least used ones (see Figure 3). Those teachers who never use video chat, do not use blogs or wikis either. However, two of those who never use video chat use communities (Facebook) a few times a week. Table 3 shows that those teachers who use ICT every day together with their students use all of the available ICT tools more often than teachers who use ICT less frequently. The greatest difference between the two groups of teachers can be seen in the use of chat as an ICT tool.

Table 3: Comparison of the average and standard deviation (stdev) of the self-estimated use of ICT tools between those teachers who use ICT with their students every day ( 7 teachers) and those who use ICT more seldom (12 teachers). The scale is 1: Every day, 2: A few times a week, 3: A few times a month, 4: hardly ever, 5: never.

\begin{tabular}{llccccccc}
\hline & Telephone & Email & $\begin{array}{c}\text { Chat } \\
\text { (text) }\end{array}$ & $\begin{array}{c}\text { Video } \\
\text { chat }\end{array}$ & Blog & Wiki & Communities \\
\hline Every day & Average & 1.14 & 1.14 & 1.86 & 4.00 & 4.57 & 4.29 & 3.86 \\
& Stdev & .378 & .378 & .690 & .577 & .535 & .951 & 1.461 \\
More & Average & 1.50 & 1.42 & 2.92 & 4.25 & 5.00 & 4.75 & 4.50 \\
seldom & & .905 & .669 & 1.379 & 1.215 & .000 & .622 & .905 \\
& Stdev & .905 & & & & &
\end{tabular}

This study took place before the introduction of remote SNE consultation. The teachers were also asked how competent they felt about engaging in remote SNE consultation. Table 4 shows the correlation between their self-estimated level of knowledge about ICT in comparison to their colleagues and how competent they feel about using remote SNE consultation. The correlation coefficient is .66, indicating a large effect size. The higher their self-estimated level of knowledge about ICT is, the more competent they feel about using remote SNE consultation. 
Table 4: The teachers' self-estimated level of knowledge about ICT in comparison to the other teachers in their school (Above average, average or below average) in relation to their selfassessed competence in remote SNE consultation. Number of teachers.

\begin{tabular}{lcccccc}
\hline & Low degree & 2 & 3 & 4 & High degree & Sum \\
\hline Above average & 0 & 0 & 1 & 3 & 2 & 6 \\
Average & 1 & 2 & 6 & 2 & 1 & 12 \\
Below average & 1 & 1 & 0 & 0 & 0 & 2 \\
\hline Sum & 2 & 3 & 7 & 5 & 3 & 20 \\
\hline
\end{tabular}

Table 5 shows the correlation between the teachers' self-estimated use of ICT in teaching and how competent they feel about using remote SNE consultation. The correlation coefficient is 0.57 , which indicates a large effect size. The more they use ICT in teaching, the more competent they feel about using remote SNE consultation.

Table 5: The teachers' self-estimated frequency of ICT use in their teaching, in relation to how competent they feel about using remote SNE consultation in special needs education. Number of teachers.

\begin{tabular}{lcccccc}
\hline & Low degree & 2 & 3 & 4 & High degree & Sum \\
\hline Every day & 0 & 0 & 2 & 2 & 3 & 7 \\
A few times a week & 0 & 1 & 3 & 1 & 0 & 5 \\
Once a week & 1 & 0 & 1 & 0 & 0 & 2 \\
A few times a month & 0 & 1 & 0 & 1 & 0 & 2 \\
Seldom of never & 1 & 1 & 1 & 0 & 0 & 3 \\
\hline Sum & 2 & 3 & 7 & 4 & 3 & 19 \\
\hline
\end{tabular}

\section{Discussion}

The aim of the present study was to shed light on whether the teacher's self-estimated ICT ability could lay a foundation for remote SNE consulting.

The study shows that teachers in rural schools are underrepresented in the research literature and that they still send out "weak signals" and have to deal with many issues on their own (c.f Pettersson, 2017). We note that very few of the previous studies on rural contexts in Sweden have had the objective to contribute knowledge about teachers' use of ICT in rural schools.

Our results show that teachers in rural schools use ICT frequently and variously. However, the teachers do not know what ICT skills their colleagues have, which might indicate that ICT use is an individual phenomenon. In order to prepare the teachers for remote SNE consulting, skills development is required (cf. Käck, 2019).

Several studies have pointed out the importance of teachers using their digital competence in teaching, for example in order to increase their repertoire of teaching methods (Drijvers et al. 2010) and to develop their students' digital skills (Krumsvik 2009) and overall performance (Bai et al. 2016). This study also shows that there is a positive correlation between teachers' self-estimated knowledge about ICT in comparison to that of their peers and their self-reported use of ICT tools together with their students. The more confident they are, the more often they use ICT tools. The 
study also shows that there is a positive correlation between the teachers' self-estimated knowledge about ICT compared to that of their colleagues, their use of ICT tools and how competent they feel about using remote SNE consultation. Those who feel more confident about their digital competence also feel more confident in their competence to use remote SNE consultation. Thus, this study indicates that the more confident the teachers feel about their general ICT competence, the higher the probability is that they will be able to implement remote SNE consultation successfully. These conclusions are also supported by the results from Käck's (2019) doctoral thesis, in which she found that teachers need an advanced level of ICT competence to be able to develop their students' digital competence. Therefore, it is important to ensure that all teachers have advanced digital skills for remote SNE consultation to be successfully introduced.

This study shows that the teachers' self-estimated digital competence differs between the age groups and teaching qualifications. The teachers with a compulsory school teacher qualification rate their knowledge about ICT higher and use ICT more frequently than those with a preschool teacher or leisure-time pedagogue qualification. This seems to indicate that different teacher education programmes provide their students with different degrees of digital competence. The compulsory school teachers seem to have acquired a higher degree of digital competence than the preschool teachers and leisure-time pedagogues. Teachers with the latter kind of qualification also usually work in preschool classes or with after-school activities, where ICT is less commonly used, which means that they will not acquire the same degree of ICT experience as teachers teaching compulsory school classes.

The differences between the age groups surprised us. In view of the rapid development of ICT in the last few decades and our expectation that more recent teacher education programmes would have given their teacher students more support in their development of digital competence, we expected that the younger teachers would estimate their digital competence to be higher than shown in this study and that they would use ICT tools more frequently than the older teachers. This expectation is also supported by the results from the studies of Hsu and Chen (2018) and Meyer and Xu (2009). Hsu and Chen (2018) found that younger teachers seem to have more technological knowledge and Meyer and Xu (2009) that older teachers find it more difficult to keep up with new technologies. However, the most confident teachers turned out to be those between 50 and 59 years old, and those teachers also use ICT tools in their teaching to a greater extent than the other groups. However, the same proportion of teachers in the age groups 30-39 and 50-59, use ICT tools with their students every day. Yet, the teachers aged between 30 and 39 did not estimate their digital competence to be at the same advanced level as that of their peers. These results raise a question: Why do the older teachers feel more confident than the younger ones, even though both groups use ICT to the same extent in their classrooms?

The teachers were asked to estimate their knowledge about ICT in relation to that of their colleagues and one explanation might be that the older teachers are more aware of their competence in comparison to that of their colleagues than the younger teachers. Younger teachers might feel less competent because they are more aware that ICT is a vast knowledge area and, as a result, they tend to underestimate their own knowledge. 
This census study only comprises 20 teachers and this may limit the generalisability of the results to teachers in general. However, as the teachers in the study are well representative of teachers nationally as regards their age (see Table 1), the results of this study should be of interest nationally, in particular for rural schools.

\section{References}

1. Abbott, M. L., \& McKinney, J. (2013). Understanding and applying research design. Somerset: Wiley.

2. Åberg-Bengtsson, L. (2009). The smaller the better? A review of research on small rural schools in Sweden. International Journal of Educational Research, 48(2), 100-108. http://dx.doi.org/10.1016/j.ijer.2009.02.007

3. Anderson, M. (2010). Images of small schools. In M. Anderson, M. Davis, P. Douglas, D., Lloyd, B. Niven, \& H. Thiele (Eds.), A collective act: Leading a small school (pp. 1-60). Melbourne: Australian Council for Educational Research.

4. Anderson, M., \& Lonsdale, M. (2014). Three Rs for rural research. I S. White, \& C. Michael (Eds.), Doing educational research in rural settings. Methodological issues, international perspectives and practical solutions (pp. 191-204). New York: Routledge.

5. Autti, O., \& Hyry-Beihammer, E. K. (2014). School closures in rural Finnish communities. Journal of Research in Rural Education, 29(1), 1-17. Retrieved from http://jrre.psu.edu/ articles/29-1.pdf

6. Bæck, U.-D. K. (2015). Rural location and academic success-Remarks on research, contextualisation and methodology. Scandinavian Journal of Educational Research, 60(4), 435-448. http://dx.doi.org/10.1080/00313831.2015.1024163

7. Bai, Y., Mo, D., Zhang, L., Boswell, M., \& Rozelle, S. (2016). The impact of integrating ICT with teaching: Evidence from a randomized controlled trial in rural schools in China. Computers \& Education, 96(2016), 1-14.

8. Berry, A. B. (2012). The relationship of perceived support to satisfaction and commitment for special education teachers in rural areas. Rural Special Education Quarterly, 31(1), 3-14.

9. Christophersen, K. A., Elstad, E., Turmo, A., \& Solhaug, T. (2016). Teacher education programmes and their contribution to pupil teacher efficacy in classroom management and pupil engagement. Scandinavian Journal of Educational Research, 60(2), 240-254.

10. Cohen, L., Manion, L., \& Morrison, K. (2011). Research Methods in Education. London: Routledge.

11. Department of Education. (2017). Nationell digitaliseringsstrategi för skolväsendet. [National strategy for digitalization in education]. Retrieved from https://www.regeringen.se/4a9d9a/contentassets/00b3d9118b0144f6bb95302f3e08d11c/natio nell-digitaliseringsstrategi-for-skolvasendet.pdf 
12. Drijvers, P., Doorman, M., Boon, P., Reed, H., \& Gravemeijer, K. (2010). The teacher and the tool: instrumental orchestrations in the technology-rich mathematics classroom. Educational Studies in Mathematics, 75(2), 213-234. https://doi.org/10.1007/s10649-010-9254-5

13. Edwards, A. (2011). Building common knowledge at the boundaries between professional practices: Relational agency and relational expertise in systems of distributed expertise. International Journal of Educational Research, 50(1), 33-39.

14. Edwards, A., \& Daniels, H. (2012). The knowledge that matters in professional practices. Journal of Education and Work, 25(1), 39-58.

15. Edwards, A., Daniels, H., Gallagher, T., Leadbetter, J., \& Warmington, P. (2009). Improving interprofessional collaborations: Learning to do multi-agency work. London: Routledge.

16. Egelund, N., \& Laustsen, H. (2006). School closure: What are the consequences for a local society? Nordic Journal of Educational Research, 50(4), 429-439.

17. European Commission. (2013). Survey of schools: ICT in education. Luxembourg: The European Union.

18. Ferrari, A. (2012). Digital Competence in Practice: An Analysis of Frameworks. Seville: Joint Research Centre. http://ftp.jrc.es/EURdoc/JRC68116.pdf

19. Garcia-Martin, S., \& Cantón-Mayo, I. (2019). Teachers 3.0: Patterns of Use of Five Digital Tools. Digital Education Review, 35, 202-215. https://doi.org/10.1344/der.2019.35.202-215

20. Hargreaves, L. M. (2009). Respect and responsibility: Review of research on small rural schools in England. International Journal of Educational Research, 48(2), 117-128. http://dx.doi.org/10.1016/j.ijer.2009.02.004

21. Howley, C., \& Howley, A. (2014). Making sense of rural educational research: Art, transgression, and other acts of terror. I S. White, \& M. Corbett (Eds.), Doing educational research in rural settings: Methodological issues, international perspectives and practical solutions (pp. 7-25). New York, NY: Routledge.

22. Håkansson Lindqvist, M. (2015). Conditions for technology enhanced learning and educational change: a case study of a 1:1 initiative. (Dissertation). Umeå: Department of Education, Umeå University.

23. Hsu, L., \& Chen, Y.-J. (2018). Teachers' Knowledge and Competence in the Digital Age: Descriptive Research within the TPACK Framework. International Journal of Information and Education Technology, 8(6), 455-458.

24. Jahnke, I., Bergström, P., Mårell-Olsson, E., Häll, L., \& Kumar, S. (2017). Digital didactical designs as research framework: iPad integration in Nordic schools. Computers \& Education, 113, 1-15. https://doi.org/10.1016/j.compedu.2017.05.006

25. Jahnke, I., \& Kumar, S. (2014). Digital didactical designs: Teachers' integration of iPads for learning-centered processes. Journal of Digital Learning in Teacher Education, 30(3), 81-88. https://doi.org/10.1080/21532974.2014.891876 
26. Käck, A. (2019). Digital competence and ways of thinking and practising in Swedish teacher education: Experiences by teachers with a foreign degree. Doctoral thesis. Stockholm: Department of Computer and System Sciences, Stockholm University.

27. Kalaoja, E. \& Pietarinen, J. (2009). Small Rural Primary Schools in Finland: A Pedagogically Valuable Part of the School Network. International Journal of Educational Research, 48(2), 109-116.

28. Karlberg-Granlund, G. (2009). Att förstå det stora i det lilla: byskolan som pedagogik, kultur och struktur [Understanding the great in the small. Pedagogy, culture and structure of the village school.] Doctoral thesis. Åbo: Åbo Akademi Universitet.

29. Karlberg-Granlund, G. (2011). Coping with the threat of closure in a small Finnish village school. Australian Journal of Education, 55(1), 62-71.

30. Kearns, R. A., Lewis, N., McCreanor, T., \& Witten, K. (2009). The status quo is not an option: Community impacts of school closure in South Taranaki, New Zealand. Journal of Rural Studies, 25(1), 131-140. http://dx.doi.org/10.1016/j.jrurstud.2008.08.002

31. Kimonen, E., \& Nevalainen, R. (2013). Preface. In E. Kimonen, \& R. Nevalainen (Eds.), Transforming Teachers Work Globally (pp. 11-147). Rotterdam: Sense Publicer.

32. Krumsvik, R. (2009). Situated Learning in the Network Society and the Digitised School. European Journal of Teacher Education, 32(2), 167-185. doi:10.1080/02619760802457224

33. Krumsvik, R. J. (2011). Digital competence in Norwegian teacher education and schools. Högre Utbildning, 1(1), 39-51.

34. Kuhl, S., Pagliano, P., \& Boon, H. (2014). In the too hard basket: Issues faced by 20 rural Australian teachers when students with disabilities are included in their secondary classes. International Journal of Inclusive Education, 19(7), 697-709.

35. Kvalsund, R. (2009). Centralised decentralisation-or decentralised centralisation? International Journal of Educational Research, 48(2), 89-99.

36. Lind, T., \& Stjernström, O. (2015). Organizational challenges for schools in rural municipalities: Cross-national comparisons in a Nordic context. Journal of Research in Rural Education, 30(6), 1-14.

37. Malloy, W. W., \& Allen, T. (2007). Teacher retention in a teacher resiliency-building rural school. The Rural Educator, 28(2), 19-27.

38. Meyer, K., \& Xu, Y. J. (2009). A casual model of factors influencing faculty use of technology. Journal of Asynchronous Learning, 13(2), 57-70.

39. McHenry-Sorber, E., \& Schafft, K. A. (2014). Make my day, shoot a teacher: Tactics of inclusion and exclusion, and the contestation of community in a rural school-community conflict. International Journal of Inclusive Education, 19(7), 733-747. 
40. Monk, D. H. (2007). Recruiting and retaining high-quality teachers in rural areas. The Future of Children, 17(1), 155-174. Retrieved from http://www.jstor.org/stable/4150024?seq=1\&cid $=$ pdf-reference\#references_tab_contents

41. Nilholm, C., \& Göransson, K. (2013). Inkluderande undervisning - vad kan man lära sig av forskningen? [Inclusive teaching- what can you learn from research] FoU, skriftserie nummer 3. Specialpedagogiska skolmyndigheten.

42. Nowotny, H. (2003). Dilemma of expertise. Democratising expertise and socially robust knowledge. Science and Public Policy, 30(3), 151-156.

43. Olofsson, A. D., \& Lindberg, J. O. (2014). Moving from theory into practice - on the informed design of educational technologies. Technology, Pedagogy and Education, 23(3), 285-291. doi:10.1080/1475939X.2014.945275

44. Perrotta, C., \& Evans, M. (2013). Instructional design or school politics? A discussion of 'orchestration' in TEL research. Journal of Computer Assisted Learning, 29(3), 260-269. https://doi.org/10.1111/j.1365-2729.2012.00494.x

45. Pettersson, G. (2017). Inre kraft och yttre tryck. Perspektiv på specialpedagogisk verksamhet $i$ glesbygdsskolor [Inner power and outer pressure : perspectives on special needs education in rural schools]. Doctoral thesis. Umeå University.

46. Pettersson, G. \& Näsström, K., (2019). Professional collaboration between class teachers and special educators in Swedish rural schools. British Journal of Special Education, 46(2), 180200.

47. Pettersson, G., Ström, K., \& Johansen JB. (2016). Teachers' Views on Support in Small Rural Schools for Students with Special Educational Needs. Nordic Studies in Education, 36(1), 2037. doi:10.18261/issn.1891-5949-2016-01-03

48. Picciano, A. G., \& Seaman, J. (2007). K-12 Online Learning: A Survey of U.S. School District Administrators.

49. SKOLFS. (2014). Skolverkets allmänna råd om arbete med extra anpassningar, särskilt stöd och åtgärdsprogram [National Agency general guidelines on working with additional adjustments, special support and action]. The Swedish National Agency for Education. Retrieved from http://www.skolverket.se/regelverk/skolfs/skolfs?_xurl_=http $\% 3 \mathrm{~A} \% 2 \mathrm{~F} \% 2$ Fwww5.skolverket.se\%2Fwtpub\%2Fws\%2Fskolfs\%2Fwpubext\%2Ffs\%2FRecord\%3Fk\%3D2903

50. Skolverket. (2018). Curriculum for the compulsory school, preschool class and school-age educare. Retrieved from https://www.skolverket.se/publikationsserier/styrdokument/2018/curriculum-for-thecompulsory-school-preschool-class-and-school-age-educare-revised-2018?id=3984

51. Spiteri. M., \& Rundgren, S.-N. C. (2017). Maltese primary teachers' digital competence: implications for continuing professional development. European Journal of Teacher Education, 40(4), 521-534, doi:10.1080/02619768.2017.1342242 
52. Swedish National Agency for Education (2018). Digitaliseringen i skolan - möjligheter och utmaningar. [Digitalizations in schools - possibilities and challenges]. Retrieved from https://www.skolverket.se/getFile?file=3971

53. Swedish National Agency for Education (2020). Statistics. Retrieved from https://www.skolverket.se/skolutveckling/statistik/sok-statistik-om-forskola-skola-ochvuxenutbildning?sok=SokC\&omrade $=$ Personal\&lasar $=2018 / 19 \&$ run $=1$

54. Svergies Riksdag. (2010). SFS 2010:800 Skollag [Educational Act]. Retrieved from https://www.riksdagen.se/sv/dokument-lagar/dokument/svenskforfattningssamling/skollag-2010800_sfs-2010-800

55. Tuters, S. (2015). Conceptualising diversity in a rural school. International Journal of Inclusive Education, 19(7), 685-696. http://dx.doi.org/10.1080/13603116.2014.964573

56. Uba, K. (2015). Protests Against the School Closure in Sweden: Accepted by Politicians? In L. Bosi, M. Giugni, \& K. Uba (Eds.), The Consequences of Social Movements (pp. 159-184). Cambridge: Cambridge University Press.

57. Warschauer, M., Zheng, B., Niiya, M., Cotten, S., \& Farkas, G. (2014). Balancing the one-toone equation: Equity and access in three laptop programs. Equity \& Excellence in Education, 47(1), 46-62. https://doi.org/10.1080/10665684.2014.866871

58. Wilson, V., \& McPake, J. (1998). Managing change in small Scottish primary schools. Edinburgh: The Scottish Council for Research in Education. 